\title{
Comparative Analysis of Regulatory and Supervisory System of Islamic Banks: Evidence from Pakistan, Malaysia, Bahrain and United Kingdom
}

\author{
Asad Khan ${ }^{1}$ \\ Sarfaraz Tanveer ${ }^{1}$ \\ Abdul Qadir Shah'1 \\ Raja Ahmed Jamil ${ }^{*}$ \\ ${ }^{1}$ Department of Management Sciences, University of Haripur, Pakistan \\ *All the correspondence should be made with Raja Ahmed Jamil, Email: raja.ahmed@uoh.edu.pk
}

\section{Doi:10.5901/mjss.2015.v6n6s2p629}

\section{Abstract}

This study has critically analysed the regulatory and supervisory framework of Islamic banks in dual banking system of Pakistan, Malaysia, Bahrain and United Kingdom. The core regulatory functions and issues are taken under discussion and results revealed that conflicting views of Islamic jurist and policy makers have further aggravated the Shariah problems. Over the years the regulatory framework in each country moulded in a peculiar way, where Malaysia and Bahrain have developed their indigenous governance systems while in United Kingdom Islamic banks are still under conventional setup. In Pakistan, Islamic banks are under the governance of orthodox regulatory framework, combined with developing Islamic banking regulatory systems. Further, the effectiveness of existing regulatory framework has never been fully challanged by extremely conservative and embryonic Islamic banking industry.

Keywords: Islamic Finance, Islamic Banking, Regulation and Supervision, Banking and Finance, Risk Management, Shariah Compliance.

\section{Introduction}

Over the past several decades, the growth in Islamic Finance (IF) and its socially responsible principles have attracted attention all over the world. The Islamic Banking and Finance (IBF) introduced in mid 60s have now global presence all over the world. But despite its tremendous growth in Islamic as well as non-Islamic countries, IBF have numerous barriers to fit in regulatory, legal and economic framework of these countries. Islamic banking is practiced in different countries under different Islamic schools of thought and laws with considerable variability in its regulatory and supervisory framework. This variability is affecting the reliability, growth and worldwide applicability as alternative system to conventional system.

This study has critically evaluated Islamic banking regulatory and supervisory structure in four diverse countries i.e. Pakistan, Malaysia, Bahrain and United Kingdom. Although all these countries except UK are Muslim majority countries, but Islamic banking in each country is practiced under relatively different regulatory and supervisory framework.

\subsection{Research Objectives}

- To document the key components of Islamic Financial industry and its regulatory and supervisory structure in selected countries.

- Comprehend and examine the institutional harmonization of governing bodies of Islamic Financial industry.

- To ascertain the extent of global harmonization of regulatory and supervisory framework of selected countries with global regulatory bodies.

To achieve the desire objectives different issues such as capital requirement, risk management, information disclosure and role of Sharia Supervisory Board, legal framework and laws for Islamic banking are taken in to consideration. As whole this study will offer a detail insight of Islamic banking regulatory and supervisory framework, and recognize its compatibility with global regulatory standards like Basel accords, AAOIFI and IFSB for banking regulation. 


\subsection{Methodology}

The research will be exploratory study in selected countries using Case Study approach. Due to the wide scope of study mostly secondary sources of data will be used. Beside conventional secondary data sources, various database and analytical tool like ThomasOne Banker, DataStream and Bloomberg will also be used to for data collection. To analyse the data, we will critically evaluate the Islamic banking regulatory and supervisory system in four Islamic countries by applying content analysis technique.

The prime reason for selecting this methodology is the complex and exploratory nature of this research. The regulatory and supervisory system of Islamic banks is multidimensional and complex area. Various issues across different geographic regions are needed to be taken in consideration. Moreover, the basic element of regulatory system such as, capital requirement, risk management framework and role of SSB etc. is almost impossible to quantify and analyse in isolation because of its interdependence. Further, each country has its own unique cultural, socioeconomic and religious (sects) values which bound them to operate and behave in a certain way. The case study approach is particularly suited for this type of research question which require detailed understanding of social and organizational processes because of the rich data collected in context (Cassell and Symon, 2004). Unlike historic viewpoint over the years there is growing confidence in the case study as a rigorous research strategy on its own right (Yin, 1994, Cassell and Symon, 2004).

\section{Literature Review}

In this section the previously available literature on Islamic banking regulation, and different problems hindered in the way to develop globally excepted regulatory and supervisory framework is reviewed.

\subsection{The Fundamentals of Islamic Finance}

The fundamental aim of Islamic financial system is to comply with guiding principles of Holy Quran, rather than maximization of return as in conventional financial system (Zaher and Hassan, 2001). According to Ayub (2007) the Islamic common law is derived from 1) Holly Quran, 2) Sunnah ${ }^{1}$ and Hadith ${ }^{2}$ of Prophet Mohammad (P.B.U.H), and other sources of Shariah are 3) ljma ${ }^{3}$ and 4) Qiyas ${ }^{4}$. Shariah does not allow financial transaction which involves Riba (Interest), Gharar (Risk/Uncertainty) and Maisir (Game of Chance) and there is complete unanimity among different schools of Islam (Khan, 2010).

\subsection{Prohibition of Riba}

The prohibition of Riba has been clearly mentioned at several places in Quran. In Surah al- Rum, verse (30:39), "That which you give as Riba to increase the people's wealth increases not with God; but that which your give in charity, seeking the goodwill of God, multiplies manifold".

Similarly the prohibition of Riba is also mentioned in Surah al-Nisa' (verse 4:161), "That they took usury, though they were forbidden; and that they devoured men's substance wrongfully; we have prepared for those among them who reject faith a grievous punishment."

In surah Surah Al-e-Imran (verse 3:130), orders the Muslims (believers) to refrain from interest for their own wellbeing. "O ye who believe! Devour not usury, doubled and multiplied; but fear Allah that ye may (really) prosper." Further in Surah al-Baqarah (verses 275-281), the glorious Quran clarify the difference between trade and interest in great details.

\subsection{Avoidance of Gharar}

Gharar is the excessive uncertainty in contracts, where details concerning the sale item are unknown or uncertain, or there is lack of information or control in a contract (Ayub, 2007). In Hadith of Holy prophet the prohibition/avoidance of

\footnotetext{
1 Practical way of life of Prophet Muhammad(P.B.U.H)

2 Sayings of Prophet Muhammad (P.B.U.H).

${ }^{3}$ Mental effort of Islamic Scholar to find solution to emerging problems and issues.

${ }_{4}^{4}$ Finding solution through analogy in the light of Quran and Sunnah
} 
Gharar is clearly mentioned in several places. Ahmad and 'Ibn Majah narrated on the authority of Abu Said Al Khudriy that "The Prophet (pbuh) has forbidden the purchase of the unborn animal in its mother's womb, the sale of the milk in the udder without measurement, the purchase of spoils of war prior to their distribution, the purchase of charities prior to their receipt, and the purchase of the catch of a diver."

\subsection{Prohibition of Maisir}

Maisir mean easily availability of wealth or acquisition of wealth, weather it deprive someone right or not (Diwany, 2010). In Holy Quran the word Maisir is used for prohibition of gambling is several places.

"O ye who believe! Intoxicants and gambling, sacrificing to stones, and divination by arrows, are an abominable action of Satan's handwork, so abstain from them, that you may prosper". (5:91)

"Satan intends to excite enmity and hatred among you with intoxicants and gambling, and hinder you from the remembrance of Allah, and from prayer; will ye not the abstain?".(5:91)

"They ask thee concerning wine and gambling. Say: 'In then is great sin and some benefits for people; but the sin is greater than the benefits". (4:219)

\subsection{Growth and Evolution of Islamic Banking and Finance}

Islamic banking started few decades ago in mid 60s from Middle East, but now it has existence in all major financial cities of the world. Karbhari, Naser and Shahin (2004) argue that, Islamic finance is one of the fastest growing phenomena in past few decades. According to BMB Islamic, (2010), the actual size of global Islamic financial industry is around \$1 trillion, with annual growth of $15 \%$ pa. Some analyst believe that, IF have the ability to capture $40 \%$ of Muslim total savings (Zaher \& Hassan, 2001). Sundararajan \& Errico (2002) argue that, to capture growing Islamic market most of the western conventional banks like HSBC, BNP Paribas and Citigroup etc. have entered Islamic banking either directly or through window operations. That is why, in past one and half decade, IF has been transformed from a niche market which existed only in few Islamic countries to a probable alternative financial system (Siddiqi, 2008; Ayub, 2007; and Chapra, 1996).

Different studies have been performed to analyse the performance and development of Islamic banks. Such as Laldin (2008) have chronologically document Malaysian Islamic financial market and its multipronged development from its inspection. In another study conducted by Lodhi and Kalim (2005) they explored the strategic policy orientation needed for the promotion of Islamic Banking in Pakistan. Similarly Anwar (1992) conducted a survey of earlier Islamic banking experience in Iran and Pakistan. Samad (2004) studied the Bahraini banking system during 1991-2001 and found that both, Islamic and conventional banks performed well in terms of profitability and liquidity, whoever Islamic banks are less expose to credit risk. In a research by Dewi, Sulaiman, and Ferdian (2010) have recently investigated the efficiency of 25 Islamic banks in 14 countries during the period of 2002 to 2006, and results revealed that Islamic banks in OIC least developed countries were more efficient. Khan and Bhatti (2008) explored the unprecedented growth and development of IF in contemporary world, across different continents of Africa, Asia, Europe and North America. In a study conducted by Verity (2002) highlighted the active role of UK government and concerned authorities to develop Islamic mortgage market in UK. Similarly Ainley et al (2007) conducted a comprehensive overview of IBF and UK government's role to resolve the Regulatory and Tax issue. Today IF attracted both Muslim and non-Muslim market participants across the globe and become the focal point of economic policy, even with most advance conventional banking sector in those countries (Monger and Rawashdeh, 2008).

\subsection{Need for Islamic Banking Regulation}

The financial crisis has revealed fundamental problems of conventional financial system besides inefficiencies and failure of regulatory and supervisory frameworks, for further detail please refer to (Goodhart and Lastra (2010), Turner Review (2009) and The De Larosiere Report (2009). Although, most of the fundamental problems like excessive leverage, risk and uncertainty, gambling like activities are by default safeguarded in IF, but these mistakes should not be repeated by IFI by ignoring basic principles of IF (Dusuki, 2008). Today, the empirical research has proved that, Islamic banks were more resilient in crisis. It is even argued that, if principles of IF had been adopted, the financial crisis would have been prevented (Ahmed, 2009; Hassan and Kayed, 2009).

But financial crisis has also increased the need to overcome the institutional and systemic irregularities, which are very much inherent in regulatory structure of IFI (Smolo and Mirakhor, 2010). These issues require timely attention, to 
sustain the growth of IFI (KFH Research, 2009). Similar study has been conducted by Ramady (2009), he analysed the role of the SAMA regulatory policies, and concluded that SAMA have complied with International financial regulation but have issues with Islamic banking regulation and supervision. The hard learned lessons from post-crisis also shows that, IFI is in urgent need to develop and implement a comprehensive, uniform and globally accepted regulatory and supervisory framework (Mirakhor and Krichene, 2009).

\subsection{Regulatory and Supervisory Issues}

In past ten years, the fast growing Islamic banking paradigm has started to create enormous issue for policy makers and regulators. Generally Islamic banks were regulated by conventional regulatory framework, as mentioned by Joyosumarto (1995) that, with slight modifications in terminologies, the profit sharing IFI are still regulated and supervised by the prudential regulation adopted for conventional banks. These issues still persists even today, as Sole (2007) argue that, the introduction of IFI in conventional system have aggravated the problem for supervisory authorities, as majority of regulatory authorities are unfamiliar with supervision of Islamic banks. He also highlighted the main phases of supervision and the challenges faced by countries operating in dual financial system.

In practice Islamic banks have distinguishing feature then its counterparts, as discussed by lqbal, Ahmad and Khan (1998), they also outlined the comprehensive institutional aspects and structural requirements for Islamic banks. Differences in theory and practice of IB in different parts of world is one of the major obstacles in uniform regulatory framework, beside other controversial issues like interbank market, Sukuk, contracts like Tawarque and Fiqah differences (Siddiqi, 2006). Similarly Karim (2001) emphasized the need of Islamic banking accounting standard harmonization with AAOIFI principles, moreover he also argue that, regulator should enforce firewalls between commercial and investment banking services offered by Islamic banks. According to El-Hawary, Grais and Iqbal (2007), various Institutions have been established notably AAOIFI, IIRA, IFSB, and LMC, but there role is limited due to divergence of theory and practice in IF and lake of risk management tool, idiosyncratic business conduct, shaped by SSB and legal traditions and interpretations of Shariah by different schools of thought (sects).

\subsection{Regulatory Capital Requirement}

Since the introduction of Islamic banking there is widely held debate that, Islamic and conventional banking are same, as Chong and Liu (2009) studied the Malaysian banking system and argue that in practice Islamic banks are not interest free or PLS, because the basic PLS contracts like Mudarabah and Musharkah are just $0.5 \%$ on assets side while ironically $70 \%$ on liability side, while other contracts are closely pegged to conventional banking. So according to his findings Islamic banks should be regulated with the same capital requirement as conventional banking. But other studies conducted by Errico and Farahbaksh (1998), Chapra and Khan (2000), Noibi, (2004) they argue that, regulatory capital requirements for conventional banks are based on their balance sheet and its debt based operations, which is completely different from profit sharing operations and risk profile of Islamic banks .

Similarly the characteristics of PSIA and their major implications from the capital adequacy and corporate governance perspectives have been analysed in the literature, notably by Al-Deehani et al. (1999), Archer et al. (1998) and Archer and Karim (2006). The PSIA possess a bulk of problem for regulators, a study conducted by Archer and Karim (2009) raised issues related to PSIAs, especially in western regulatory jurisdiction where customer accounts are 'capital certain' and equity type investment, without any governance rights. To resolve these problems they offered a solution in the form of a structural distinction between the Islamic banks in the narrow sense on one side, and the entity that manages the PSIA on the other hand.

According to Errico and Farahbaksh (1998) the "number of standards and best practices established by the Basle Committee on Banking Supervision.....are not always applicable [as they stand] to Islamic banking. An appropriate regulatory framework governing Islamic banks needs to place greater emphasis on the management of operational risks and information disclosure than is normally the case in conventional banking". However, the first comprehensive work to conceptualize the need to identify the risks and to regulate Islamic banks was carried out by Chapra and Khan (2000), they discussed the regulatory and supervisory challenges to calculate capital requirement and risk associated with IB. Similarly Noibi (2004) also discussed the applicability of Basle Committee regulatory frame to Islamic banking operations, and it was established that it is not compatible with Islamic banking.

Serious efforts have been made by AAOIFI (1999) and the IFSB (2005) to address the issues of regulatory capital requirement and unique risk profile of Islamic banks. But these standards are still at evolutionary stage as Muljawan, Dar, and Hall (2004) have critically evaluated the capital adequacy frame work defined by AAOIFI for IFI and raised some 
serious issues on established standards, they also proposed new frame after analysing the criticism of proposed framework. Ariss and Sarieddine (2007) studied the implications of Pillar 1 of the Basel II accord to Islamic banks following the IFSB and the AAOIFI guidelines, and recommended proposals for developing a capital adequacy framework that better accounts for Islamic banks activities. Similarly Archer, Karim and Sundararajan (2010) established a quantitative analytical framework for the exercise of supervisory discretion on "alpha" to assess the adequacy of Islamic banks capital. Further the CAR is highly sensitive to value of "alpha", and CAR calculated without reasonable care will lead to an adequate measure of Islamic banks capital requirement. Hersh (2011) explain the regulatory framework of Bahrain, and emphasized the role of IFSB to fill the regulatory gaps between Islamic and conventional banking.

\subsection{Information Disclosure and Risk Management}

In context of Islamic banking the main objective of corporate reporting is to allow IFI to show their compliance with Shariah (Baydoun and Willett, 1997, p. 6). As PLS modes of financing raise several considerations for regulators, specifically, when different risks are directly transferred to investment account holders of a bank. Therefore a clear information disclosure system in Islamic banks is more important than the conventional banks (Jabbar, 2010). According to Makiyan (2008) Islamic banks are exposed to unique risks, which are inherent in PLS operations, therefore greater need for information disclosure is required to keep the regulator and investor updated and to monitor banks performance. In research by Ariffin, Archer and Karim (2009a) investigated the issue of transparency in 28 Islamic banks in 14 countries by questionnaire survey. The finding of this survey revealed that Islamic banks are still lack information disclosure on issue of risk management, investments and corporate governance. The findings of the study have both theoretical and policy implications for the issue of transparency, with particular reference to risk reporting in Islamic banks.

In another study conducted by Ariffin, Archer and Karim (2009b) they studied the risk perception of Islamic bankers regarding risk significance, risk measurement and risk management techniques. The result obtained from 28 banks across 14 countries using questionnaire and interviews (wherever possible) indicates that, Islamic banks are exposed to similar risks as their counterparts, but level of risk is different for different products and contracts. To harmonize the issue of risk identification and management, the IFSB (2005) outlined best principles for establishing and implementation of risk management in IFI by identifying the six risk categories; credit risk, equity investment risk, market risk, liquidity risk, rate of return risk and operational risk. These principle guidelines will help in standardization of risk exposure in Islamic banking. Similarly to address the issue of public information disclosure IFSB (2007) have also issued standards on Disclosures to Promote Transparency and Market Discipline for Institutions offering Islamic Financial Services (excluding Islamic Insurance and Islamic Mutual Funds).

In a very comprehensive study conducted by Maali, Casson and Napier (2006) developed a benchmark set of social disclosure on the basis of importance given to social responsibilities and accountability by Islamic principles in a society. These benchmark set are compared with social disclosure contained in annual reports of 29 Islamic banks around globe, using a disclosure index approach. The results revealed that information disclosure are below the expectation in Islamic banks. Similarly in study conducted by Besar et al (2009) have critically evaluated the roles, responsibilities and Shariah review reports issued by SSB under the guidelines issued by AAIOIFI and BNM to evaluate Islamic banks in Malaysia. The results revealed that banks review reports issued by Shariah Committees (SSB) only maintain minimum requirement set by BNM.

\subsection{Role of Shariah Supervisory Board}

The function of compliance and supervision in Islamic banking is performed by SSB and its basic objective is to observe the legitimacy of Islamic banking activities according to Shariah. In case of Islamic banks, the challenge for SSB are becoming more and more complicated, as the scholars have to look into more sophisticated contracts and instruments that are constantly being developed by the industry (Sa'Pinto, 2009). The significance of SSB is stressed by Dar (2011a) where he highlighted the fact that, the importance of the Shariah audit function is even more profound for conventional institutions offering Islamic financial services for a number of reasons. In other article by Dar (2011b) explained the role of classical Shariah scholars and their influence in different geographic area around the world, this show there is no wide spread consensus among these Shariah scholars.

The growth and innovation have also increased compliance issue of Islamic banks as Jabbar (2010) established the fact that financial crimes (like insider dealing, market abuse, fraud and money Laundering etc) are prohibited in Islam so it's the responsibility of SSBs to oversee these issues, but at the moment SSBs neither have the capacity neither have 
time and resource to fulfil these basic duties. In a study by Farook and Farooq (2011), raised different Shariah related issues like, concentration of Shariah scholars, multiple boards representation, knowledge and due diligence and selection criteria by shareholders of IFI, further they also recommended solutions to organize and develop Shariah scholars to increase the legitimacy of Islamic industry. Zaidi (2008) argue that, there are different schools of thoughts, whose opinions are different on specific issues, but have consensus on major issues. So the matter of Shariah harmonization must be left for Shariah scholars, as they are specialized in their field. Further he suggests that, Shariah harmonization require collaboration between Shariah scholars, market leaders and regulator, which can be achieved by Supreme Shariah body.

\subsection{Legal Issues}

With increasing market share of Islamic banks, the importance and need of Islamic law is now felt desperately. There is growing concerns over existing laws of countries where Islamic banks operates that, weather, they fully accommodates Islamic financial transactions (Hesse, Jobst, and Solé, 2008). Although in some literature researchers holds the view that in most jurisdictions the conventional law is flexible enough to accommodate the agreed terms and conditions of contracting parties (DeLorenzo and McMillen, 2007). But in practice it is very difficult as we have seen in Kingdom of Saudi Arabia (KSA), whose legal system is based on strict Shariah principles, but lots of problems were created by various defaulters of IFI due to duality is Saudi legal system (Marar, 2004). Same is the case with other countries like UK, in a study conducted by Ercanbrack (2011) he explained the role of English courts and unwillingness to comply with Sharia rules.

According to Khan (2007) the differences in Fiqh opinion are not a problem at the moment, but in future it will be a big challenge for regulators. Moreover he stressed the need of institutional arrangement to regulate the diversity in Shariah rules with other regulatory and supervisory issues. Other issues like dispute resolution is also a concern for Islamic banks, Oseni (2009) argue that, the dispute resolution in IF is still a major issue, which is handled by conventional law and legal system. He analyse different case from various countries and concluded that separate legal frame work should be established for IBF.

\subsection{Liquidity Management and Consumer Safety Net}

Basic infrastructural element of financial system like Inter-bank money Market and Deposit Issuance are extremely essential for Islamic banks to carry out their daily operations and consumer safety. But despite being the cornerstone of efficient banking system, these elements are still at embryonic stage, with a lot of disagreements at different geographic regions (Solé, 2007). Malaysia and Bahrain made a considerable effort to develop Islamic banks liquidity management system. In a study Bacha (2008) briefly explained BNM's initiative in establishing the Islamic Inter-bank Money Market (IIMM) and also examines the issues and challenges that faced by IIMM that operates within a dual banking system. Turkey was the first to take the initiative in 2003, to establish Shariah complied deposit insurance for Islamic banks, where all the Islamic banks are allowed to create an Islamic deposit takaful (IADI, 2006). It was followed by Malaysia by approval of Malaysia Deposit Insurance Corporation Act in August 2005 (BNM 2005).

\section{Comparative Analysis}

In this section a comprehensive comparative analysis for different regulatory and supervisory issue of Islamic banks in four countries are document, the consolidated analysis is given in below.

\section{Table 1}

\begin{tabular}{|l|l|l|l|l|}
\hline Comparative Analyses & Pakistan & Malaysia & Bahrain & United Kingdom \\
\hline $\begin{array}{l}\text { Development of IB and its } \\
\text { Regulatory system }\end{array}$ & $\begin{array}{l}\text { Initially Revolutionary but failed. } \\
\text { Now Evolutionary }\end{array}$ & Evolutionary & Evolutionary & Evolutionary \\
\hline Scope of Regulatory Authorities & Multiple Regulators & Multiple Regulators & Single regulator & Single regulator \\
\hline Regulatory framework for IB & Mixed Regulatory setup for IB & $\begin{array}{l}\text { Separate Regulatory } \\
\text { setup for IB }\end{array}$ & $\begin{array}{l}\text { Separate Regulatory } \\
\text { setup for IB }\end{array}$ & $\begin{array}{l}\text { Regulated by Conventional } \\
\text { setup }\end{array}$ \\
\hline $\begin{array}{l}\text { Accountability and Funding of } \\
\text { regulatory authorities }\end{array}$ & $\begin{array}{l}\text { Accountable to Parliament } \\
\text { through MoF \& Government } \\
\text { Funded }\end{array}$ & $\begin{array}{l}\text { Accountable to } \\
\text { Parliament through MoF } \\
\text { \& Government Funded }\end{array}$ & $\begin{array}{l}\text { Accountable to } \\
\text { Parliament through } \\
\text { MoF \& Government }\end{array}$ & $\begin{array}{l}\text { Accountable to Parliament } \\
\text { through HM Treasury \& Self- } \\
\text { Funded }\end{array}$ \\
\hline
\end{tabular}




\begin{tabular}{|c|c|c|c|c|}
\hline & & & Funded & \\
\hline Licensing and Authorization & Under SBP & Under BNM & Under CBB & Under FSA \\
\hline Consumer protection for IB & Not Available & Available & Available & $\begin{array}{l}\text { Available but not dedicated for } \\
\text { IB }\end{array}$ \\
\hline Supervisory System & $\begin{array}{l}\text { CAMEL/CAEL with Onsite \& } \\
\text { offsite Supervision }\end{array}$ & $\begin{array}{l}\text { Risk-Based Supervisory } \\
\text { Framework. }\end{array}$ & $\begin{array}{l}\text { Onsite Supervision \& } \\
\text { offsite Surveillance }\end{array}$ & $\begin{array}{l}\text { ARROW framework with } \\
\text { Onsite Supervision \& offsite } \\
\text { Surveillance }\end{array}$ \\
\hline $\begin{array}{l}\text { Capital Adequacy standards for } \\
\text { IB }\end{array}$ & $\begin{array}{l}\text { In process but currently under } \\
\text { Conventional setup }\end{array}$ & $\begin{array}{l}\text { Exist and Compatible with } \\
\text { IFSB \& Basle }\end{array}$ & $\begin{array}{l}\text { Exist and Compatible } \\
\text { with IFSB \& Basle }\end{array}$ & Conventional Framework \\
\hline $\begin{array}{l}\text { Risk Management standards for } \\
\text { IB }\end{array}$ & Exist and Compatible with IFSB & $\begin{array}{l}\text { No specific risk } \\
\text { management standards }\end{array}$ & $\begin{array}{l}\text { Exist and Compatible } \\
\text { with IFSB }\end{array}$ & Conventional Framework \\
\hline $\begin{array}{l}\text { Information Disclosure } \\
\text { standards for IB }\end{array}$ & $\begin{array}{l}\text { Exist but vey general compared } \\
\text { to IFSB }\end{array}$ & Exist & Exist & Conventional Framework \\
\hline $\begin{array}{l}\text { Corporate Governance } \\
\text { standards for IB } \\
\end{array}$ & Conventional Framework & Exist & Exist & Conventional Framework \\
\hline $\begin{array}{l}\text { Dedicated Accounting } \\
\text { Standards for IB }\end{array}$ & $\begin{array}{l}\text { SECP accounting standards } \\
\text { Not fully developed but follow } \\
\text { AAOIFI }\end{array}$ & $\begin{array}{l}\text { Fully exist but follow } \\
\text { MASB accounting } \\
\text { standards }\end{array}$ & $\begin{array}{l}\text { Completely follow } \\
\text { AAOIFI }\end{array}$ & Follow IAS/IFRS \\
\hline Role of Shariah Board & $\begin{array}{l}\text { Appellate SSB at SBP and SSB } \\
\text { also exist at Banks level }\end{array}$ & $\begin{array}{l}\text { Appellate SAC at BNM } \\
\text { and SSB also exist at } \\
\text { Banks level }\end{array}$ & $\begin{array}{l}\text { SSB exist only at } \\
\text { Banks level \& must } \\
\text { follow AAOIFI } \\
\text { standards }\end{array}$ & $\begin{array}{l}\text { SSB exist only at Banks level \& } \\
\text { FSA is not concerned with it }\end{array}$ \\
\hline Institutional Harmonization & Low & High & Medium & Low \\
\hline
\end{tabular}

\subsection{The Scope of Regulatory Authorities}

Among the four countries UK and Bahrain have single regulatory system for whole financial sector. While in Malaysia and Pakistan the financial sector is regulated by different regulatory bodies. Moreover, UK is the only country, whose financial regulatory body is separate from its central bank, which also looks after the economic affairs of the country.

\subsection{Historically Development of Regulatory System}

The regulatory systems of respective countries are mostly evolutionary and planned except Pakistan, mainly because of its unique governance and constitutional binding to bring all financial affairs of country under Shariah. Only Malaysia enacted separate law to operationalize Islamic banks, while rest just amended current laws. Moreover, during the evolution most countries regulatory system transformed or transforming towards principle based regulation where UK has completely principle based system while Pakistan is still predominantly rule based.

\subsection{Separate Regulatory Setup For Islamic Banks}

As whole all countries have developed or developing separate regulatory/supervisory setup for Islamic banking except UK where Islamic banks are completely under the governance of conventional setup.

\subsection{Accountability Funding and Governance of Concerned Authorities.}

The regulatory bodies of all counties are accountable to government via its boards. The members of BOD and top management are mostly appointed by Head of States except in UK, where this function is performed by HM Treasury. Moreover all regulatory bodies are government funded except UK which has its own revenue sources from regulated firms.

\subsection{Consumer Protection}

Except in Pakistan, all other three countries have consumer safety programs for its IBI. But its validity under Shariah principles is still not certain and under debate among various Islamic jurists across the globe. Among them Malaysia have completely separated its deposit insurance scheme for Islamic banks from conventional counterparts. 


\subsection{Licensing and Authorization}

The licensing and authorization of Islamic banks in all countries are under the jurisdiction of its concern regulatory authorities and central banks.

\subsection{Supervision}

All the counties have completely different supervisory frameworks and offsite surveillance system. But the nature and frequency of onsite supervision is mostly subject to the ranking, financial conditions, risk profile and conduct of business of an IFI.

\subsection{Regulatory Capital}

All countries are in complete compliance with Basel Capital requirements, but huge divergence exists in guidelines followed by Islamic banks. Malaysia and Bahrain have enacted separate guidelines for Islamic banks regulatory capital calculation under the guiding principles of IFSB. While UK and Pakistan have adopted conventional framework of capital calculation for Islamic banks, but in Pakistan a separate framework is also under development.

\section{Table 2}

\begin{tabular}{|l|c|c|c|c|c|}
\hline Capital Requirement and Standards \\
\hline Characteristics of Capital Requirement & Pakistan & Malaysia & Bahrain & United Kingdom & \multicolumn{1}{|c|}{ Comments } \\
\hline Follow Basel Capital Standards & Yes & Yes & Yes & Yes & \\
\hline Dedicated Standards set by respective regulators & No & Yes & Yes & No & \\
\hline Compliance with IFSB guidelines & No & Yes & Yes & No & \\
\hline $\begin{array}{l}\text { Standardization of Capital Standards among } \\
\text { each other }\end{array}$ & No & No & No & No & $\begin{array}{l}\text { Every country has separate } \\
\text { guidelines }\end{array}$ \\
\hline
\end{tabular}

\subsection{Risk Management Framework}

Except in UK, every country has tailored risk management framework for Islamic banks under the guiding principles of IFSB. But there is complete divergence to specific types of risks among the sampled countries and each country has set its own guidelines according to the type and nature of risks in its financial industry. Moreover the effectiveness of these guidelines at critical situation is also a major concern among industry practitioners.

\section{Table 3}

\begin{tabular}{|l|c|c|c|c|c|}
\hline \multicolumn{7}{|c|}{ Risk Management Framework } \\
\hline $\begin{array}{l}\text { Characteristics of Risk } \\
\text { Management Framework }\end{array}$ & Pakistan & Malaysia & Bahrain & United Kingdom & Comments \\
\hline $\begin{array}{l}\text { Dedicated Presence of Risk } \\
\text { Management framework }\end{array}$ & Yes & No & Yes & No & $\begin{array}{l}\text { UK is following Basel } \\
\text { with ARROW approach }\end{array}$ \\
\hline Compliance with IFSB & Yes & Yes & Yes & No & \\
\hline $\begin{array}{l}\text { Scope of Risk Management } \\
\text { Framework }\end{array}$ & $\begin{array}{l}\text { Principles Cover } \\
\text { Six type of Risk }\end{array}$ & $\begin{array}{l}\text { Broad Principles } \\
\text { are adopted }\end{array}$ & $\begin{array}{l}\text { Only Credit, Market } \\
\text { \& Operational }\end{array}$ & $\begin{array}{l}\text { Completely adopted } \\
\text { Basel framework }\end{array}$ & \\
\hline
\end{tabular}

\subsection{Role of Shariah Board}

The role SSB is very central to IB, but complete disagreement exists across the selected countries. At one end Malaysia has established a comprehensive framework for Shariah compliance/application with very little chance of misunderstanding at operational level. But on the other hand we have UK, where regulators are not concerned at all about Shariah compliance and matter is completely delegated to IFI to select the framework suitable for them, but subject to proper disclosure to its Stakeholders. In between we have Pakistan and Bahrain, which have well-structured Shariah compliance system but different in its own. The Shariah implementation structure in Pakistan is similar to Malaysia, with main SSB established at SBP level, with limited powers compared to Malaysia SAC, and also at institutional level. While in Bahrain Shariah boards exist only at institutional level and there is no central SSB at CBB. 


\section{Table 4}

\begin{tabular}{|l|c|c|c|c|c|l|}
\hline Role of Shariah Supervisory Boards & Pakistan & Malaysia & Bahrain & United Kingdom & Comments \\
\hline Characteristics of SSB & Yes & Yes & No & No & \\
\hline Presence of SSB at Main Regulatory Level & No & Yes & No & No & $\begin{array}{l}\text { Malaysia SAC have } \\
\text { complete Authority }\end{array}$ \\
\hline Complete Authority our all Shariah Issues in Country & Yes & Yes & Yes & Yes & $\begin{array}{l}\text { In UK its Optional, for rest } \\
\text { Mandatory }\end{array}$ \\
\hline Presence of SSB/Committees at Islamic Banks level & Yes & Yes & No & No & $\begin{array}{l}\text { Bahrain follow AAOIFI } \\
\text { Shariah Standards }\end{array}$ \\
\hline Separate Guidelines on Shariah Compliance & Yes & No & Yes & No & \\
\hline Compliance with AAOIFI Shariah standards & & & &
\end{tabular}

\subsection{Corporate Governance}

Bahrain and Malaysia have tailored corporate governance framework under the guiding principles of IFSB and keeping in view local circumstance, to specifically address the issues in Islamic banks. While in UK and Pakistan the corporate governance standards which are set for conventional industry is also followed by Islamic banks.

\subsection{Accounting Standards}

The AAOIFI was established with basic objective to establish accounting standards for Islamic banks. But at moment Bahrain is only country who has completely adopted AAOIFI accounting standards while Malaysia and Pakistan is using it indirectly. But on the other side UK have completely different accounting standards under IASs/IFRS.

\section{Table 5}

\begin{tabular}{|l|c|c|c|c|c|c|}
\hline Accounting Standards \\
\hline Characteristics of Accounting Standards & Pakistan & Malaysia & Bahrain & United Kingdom & Comments \\
\hline Dedicated Accounting Standards & Yes & Yes & Yes & No & In Pakistan it is partially developed. \\
\hline Compliance with AAOIFI Standards & Yes & No & Yes & No & \\
\hline
\end{tabular}

\subsection{Information Disclosure}

Regulation and guidelines exists for information disclosure in all countries, but its effectiveness is big question. Although, UK have well established information disclosure standards and practices, but it is only for conventional banks. Moreover in Pakistan information disclosure standards exist but very basic.

\section{Table 6}

\begin{tabular}{|l|c|c|c|c|c|}
\hline Information Disclosure \\
\hline Characteristics of Information Disclosure & Pakistan & Malaysia & Bahrain & United Kingdom & Comments \\
\hline Dedicated Guidelines for Information Disclosure & Yes & Yes & Yes & No & \\
\hline Compliance with IFSB & No & Yes & Yes & No & \\
\hline
\end{tabular}

\subsection{Institutional Harmonization}

Institutional harmonization is very pivotal for the success Islamic banking. Only Malaysia have well developed institutional framework, where each institution like Judiciary, Money market etc is well organized under a planned strategy from government. Other than Malaysia in remaining countries have very underdeveloped and conflicting institutional structure exists, which may or will create problem in Islamic banking operations.

\subsection{Role of International Standard Setting Organization}

The role of international standard-setting bodies like AAOIFI, IFSB etc is generally acknowledged at policy level but very limited to geographic area of these institutions at operational level. 


\section{Conclusions}

The constant support for development of IBF from regulators and governments were predominantly due to economic rational rather than religious motivation, except in Pakistan where revolutionary actions were taken in past but failed. Historically Islamic banks were under conventional setup but with enlargement of Islamic financial industry each country adopted separate regulatory structure based on its institutional setup and market dynamics. This segregation of regulatory framework also established the fact that Islamic banks need separate governance structure and its social responsible objectives and operational efficiencies cannot be achieved under conventional setup.

At moment the global harmonization of prudential standards and guiding principles is not a primary concern among different regulators, which resulted in indigenous regulatory setup. Among these the most prominent and important is Shariah Supervisory Boards/Councils, despite its pivotal role, there is complete divergence among different countries, which is mostly influenced by its institutional framework and sectarian thoughts. Further the regulatory frameworks for capital requirement, corporate governance, risk management and financial reporting exits and considerably complying with international standards, but how much effective they are, these questions can only be answered when IFI get indulge in widespread financial activities at mass level. As whole the guiding principles for regulatory functions are defined in such a way that it overlaps each other and can't be clearly applied, which further raised the industry concerns. A significant development in regulation of Islamic banks is its tendency towards the principle based regulation which will empower greater responsibilities at operational level which is very much needed in Islamic banks.

The Islamic banks in UK are still under the conventional setup, mainly because of government's secular policy and relatively smaller size of Islamic banking as compared to its conventional counterparts. As a whole Malaysia is in forefront among the four countries, with completely harmonized and developed regulatory systems for Islamic banks. We can also conclude that, the success of IBF and its increasing market share have increased its viability in a financial system, but it is certainly not in a position to give a full-fledged alternative financial system in any country at the moment. Infect with passage of time the introduction of new products and means will enable Islamic and conventional banks to better collaborate within dual banking system.

\section{References}

AAOIFI (1999) 'Statement on the Purpose and Calculation of the Capital Adequacy Ratio for Islamic Banks' [online], Available at: http://www.aaoifi.com/keypublications.html

Ahmed, H. (2009) 'Financial crisis risks and lessons for Islamic finance', ISRA International Journal of Islamic Finance, 1(1), pp. 7-32.

Ainley, M., Mashayekhi, A., Hicks, R., Rahman, A. and Ravalia, A (2007) Islamic Finance in the UK: Regulation and Challenges, [online].Available at: http://www.fsa.gov.uk/pubs/other/islamic_finance.pdf

Al-Deehani, T., Karim, R.A.A. and Murinde, V. (1999) 'The capital structure of Islamic banks under the contractual obligation of profit sharing', International Journal of Theoretical and Applied Finance, 2(3), pp. 243-83.

Anwar, M. (1992) 'Islamic Banking in Iran and Pakistan: A Comparative Study', The Pakistan Development Review, 31(4), pp. 10891097.

Archer, A., Karim, R.A.A. and Sundararajan, V (2010) 'Supervisory, regulatory, and capital adequacy implications of profit-sharing investment accounts in Islamic finance', Journal of Islamic Accounting and Business Research, 1(1), pp. 10-31

Archer, S., Karim, R.A.A. and Al-Deehani, T. (1998) 'Financial contracting, governance structures and the accounting regulation of Islamic banks: an analysis in terms of agency theory and transaction cost economics', Journal of Management and Governance, pp. $149-70$

Archer, S. and Karim, R.A.A. (2006) 'On capital structure, risk sharing and capital adequacy in Islamic banks', International Journal of Theoretical and Applied Finance, 9(3), pp. 269-80.

Archer, S and Karim, R.A.A. (2009) 'Profit-sharing investment accounts in Islamic banks: Regulatory problems and possible solutions', Journal of Banking Regulation, 10(4), pp. 300-306.

Ariffin, N. M., Archer, S. and Karim, R.A. A (2009a) 'Issues of Transparency in Islamic Banks', Review of Islamic Economics, 13(1), pp. 89-104.

Ariffin, N. M., Archer, S. and Karim, R.A. A (2009b) 'Risks in Islamic banks: Evidence from Empirical research', Journal of Banking Regulation, Vol. 10(2), pp. 153-163.

Ariss, R.T and Sarieddine, Y. (2007) 'Challenges in implementing capital adequacy guidelines to Islamic banks', Journal of Banking Regulation, 9(1), pp. 46-59.

Ayub, M. (2007) Understanding Islamic Finance. illustrated edition. John Wiley \& Sons.

Bacha, O. I. (2008) 'The Islamic Interbank Money Market and a Dual Banking System : The Malaysian experience', International Journal of Islamic and Middle Eastern Finance and Management , 1(3), pp. 210-226.

Baydoun, N., and R. Willett ( 1997) 'Islam Ethical Issues in the Presentation of Financial Information', Accounting, Commerce and Finance: The Islamic Perspective Journal, 1(1). 
Besar, M.H.A.H., Nuraishah, M.E.A.S., Muthalib, A., and Gunawa, A.Y.(2009) 'The Practice of Shariah Review as Undertaken by Islamic Banking Sector in Malaysia', International Review of Business Research Papers, 5 (1), pp. 294-306.

BMB Islamic (2010) Global Islamic Finance Report, United Kingdom

Cassell, C and Symon, G. (2004) Essential guide to qualitative methods in organizational research, $1^{\text {st }}$ ede. London: SAGE.

Chapra, M.U.(1996) What is Islamic Economics, 1'st edn. Jeddah: Islamic Development Bank.

Chapra, M.U. and Khan, T.U. (2000) Regulation and Supervision of Islamic Banks, Islamic Research and Training Institute, Islamic Development Bank. Available at: http://www.isdb.org/irj/go/km/docs/documents/IDBDevelopments/lnternet/English/IDB/CM/ Publications/Occasional\%20Papers/Islamic\%20Banking\%20and\%20Finance/Regulations_Supervision_of_Islamic_Banks.pdf

Chong, B.S. and Liu, M.H. (2009) 'Islamic banking: Interest-free or interest-based?', Pacific-Basin Finance Journal, 17(1), pp. 125-144.

Dar, H (2011a) Shari'a leaders in Islamic finance, Business Asia Weekly, 1 (40), pp.11. Available at http://businessasiaweekly.com/ admin_cp_se/upload/issue_pages/pdf_1161_Page\%2011.pdf

Dar, $\mathrm{H}(2011 \mathrm{~b})$ Importance of Shari'a audit for conventional banks offering Islamic financial products, Business Asia Weekly, 1 (42), pp. 11. Available at: http://www.businessasiaweekly.com/admin_cp_se/upload/issue_pages/pdf_1209_Page\%2011.pdf

Dewi, M, K., Sulaiman, M and Ferdian, I.R (2010) 'Efficiency of Islamic banks in selected member countries of the Organisation of Islamic Conference', International Journal of Monetary Economics and Finance, 3(2), pp.177-205

Diwany, T.E (2010) Islamic Banking and Finance. 1'st edn. Bolton: 1sr Ethical Charitable Trust.

Dusuki, A.W (2010) 'Understanding the objectives of Islamic banking: a survey of stakeholders' perspectives', International Journal of Islamic and Middle Eastern Finance and Management, Vol. 1(2), pp. 132-148

El-Hawary, D., Grais, W. and Iqbal, Z (2007) 'Diversity in the regulation of Islamic Financial Institutions', The Quarterly Review of Economics and Finance, 46, 778-800

Ercanbrack, J (2011) 'The regulation of Islamic finance in the United Kingdom', Ecclesiastical Law Journal, 13(1), pp. 69-77.

Errico, L., \& Farahbaksh, M. (1998). Islamic banking: issues in prudential regulations and supervision,Working paper, International Monetary Fund.

Farook, S.Z and Farooq, M.O (2011) 'Shariah Governance for Islamic Finance: Challenges and Pragmatic Solutions', Available at SSRN: http://ssrn.com/abstract=1813483

Goodhart, C.A.E and Lastra R,M. (2010) 'Border Problems', Journal of International Economic Law, 13(3),pp. 705-718.

Hassan, M.K. and Kayed, R.N. (2009a) 'Can the Islamic financial system withstand the current financial crisis?', ISRA Bulletin, Vol. 4, pp. 13-15.

Hersh, E.S. (2011) 'Islamic Finance and International Financial Regulation', Journal of International Service. Available at:http://journalofinternationalservice.org/wp-content/uploads/2011/01/4Hersh.pdf.

Hesse, H., Jobst, A.A and Solé, J(2008) 'Trends and Challenges in Islamic Finance', World Economics, 9(2).

IADI (2006) Update on Islamic Deposit Insurance Issues, Research Letter, Vol. 1 No. 3. Available at: http://www.iadi.org/research_ letters/vol1/IADI ResearchLetter Vol1 Iss3.pdf

Iqbal, M., Ahmad, A., and Khan, T (1998) Challenges facing Islamic banking: Occasional paper- No.1, Islamic Economy, Islamic research and training institute Islamic Development Bank.

IFSB (2005) Capital Adequacy Standard for Institutions (Other than Insurance Institutions) Offering Only Islamic Financial Services, [Online]. Available at: http://www.ifsb.org/standard/ifsb2.pdf

IFSB (2005) Guiding Principles of Risk Management for Institutions (Other than Insurance Institutions) Offering Only Islamic Financial Services, [Online]. Available at: http://www.ifsb.org/standard/ifsb1.pdf.

IFSB (2007). Disclosures to Promote Transparency and Market Discipline for Institutions offering Islamic Financial Services (excluding Islamic Insurance and Islamic Mutual Fund), [Online]. Available at: http://www.ifsb.org/standard/ifsb4.pdf.

Jabbar, S.F.A (2010) 'Financial crimes Prohibition in Islam and prevention by the Shari 'a Supervisory Board of Islamic financial institutions', Journal of Financial Crime, 17 (3), pp. 287-294

Jacques de Larosière(2009) The high-level group on financial supervision in the EU. Available at:http://ec.europa.eu/internal market/finances/docs/de_larosiere_report_en.pdf.

Joyosumarto, S. (1995) The role of central banks in regulating Islamic banks in a dual banking system: the case of Indonesia. In: Proceedings of the 9th Expert-Level Conference on Islamic Banks, Jakarta, Indonesia.pp. 3-17.

Karbhari, Y., Naser, K., Shahin, Z (2004) 'Problems and Challenges Facing the Islamic Banking System in the West: The Case of the UK', Thunderbird International Business Review, 46(5), pp.521-543.

Karim, R. A. A (2001) 'International accounting harmonization, banking regulation and Islamic banks', The International Journal of Accounting, 36(2), pp.169-193.

Khan, M. F. (2010) 'How 'Islamic' is Islamic Banking?', Journal of Economic Behavior \& Organization, 76, pp. 805-820.

Khan, M. M. and Bhatti, M. I (2008) 'Islamic banking and finance: on its way to globalization', Managerial Finance, 34 (10), pp. 708-725

Laldin, M, A (2008) 'Islamic financial system: the Malaysian experience and the way forward', The International Journal of Systems and Ethics, 24(3), pp. 217-238.

Lodhi, S, A,. and Kalim, R(2005) 'Strategic Directions for Developing an Islamic Banking System', The Pakistan Development Review, 44(4),pp. 1003-1020.

Maali, B., Casson, P. and Napier, C. (2006) 'Social Reporting by Islamic Banks', ABACUS, 42(2), pp. 266-289.

Makiyan, S.N (2008) Risk Management and Challenges in Islamic Banks, Journal of Islamic Economics, Banking and Finance. Available at: http://www.ibtra.com/pdf/journal/v4_n3_article3.pdf. 
Marar, A.D (2004) 'Saudi Arabia: The Duality of the Legal System and the Challenge of Adapting Law to Market Economies', Arab Law Quarterly, 19(1/4), pp. 91-123

Mirakhor, A. and Krichene, N (2009) Recent crisis: lessons for Islamic finance, IFSB 2nd Public Lecture on Financial Policy and Stability, Islamic Financial Services Board (IFSB), Kuala Lumpur

Monger, R. and Rawashdeh, M. (2008) 'Islamic finance enters the mainstream', Management Acounting Quarterly, 9(3), pp. 1-6.

Muljawan, D., Dar, H.A. and Hall, M. J.B. (2004) 'A Capital Adequacy Framework for Islamic Banks: The Need to Reconcile Depositors' Risk Aversion With Managers' Risk Taking', Applied Financial Economics, 14 (6), pp. 429 - 441.

Noibi, M. A (2004) 'Islamic Banks: An Analysis of Capital Adequacy Standards', Review of Islamic Economics, 8(1).

Oseni, U. A (2009) Dispute Resolution in Islamic Banking and Finance: Current Trends and Future Perspectives, International Conference on Islamic Financial Services: Emerging Opportunities for Law/Economic Reforms of the Developing Nations, 6 - 8 October, 2009, Nigeria. Available at: http://ssrn.com/abstract=1461895

Ramady, M, A. (2009) 'Evolving banking regulation and supervision: A case study of the Saudi Arabian Monetary Agency (SAMA)', International Journal of Islamic and Middle Eastern Finance and Management, 2 (3), pp.235 - 250.

Sa'Pinto, M. (2009) 'Islamic finance needs consistency: Faisal Pvt Bank CEO', Reuters, 15 April, [online]. Available at: www.reuters.com/article/rbssBanks/idUSLF51051620090415

Samad, A. (2004) 'Performance of Interest-Free Islamic Banks VIS-A-VIS Interest-Based Conventional Banks of Bahrain', IIUM Journal of Economics and Management, 2, pp. 2-15.

Siddiqi, M.N (2006) 'Islamic Banking And Finance In Theory And Practice: A Survey Of State Of The Art', Islamic Economic Studies, 13(2).

Siddiqi, M.N.(2008) "Current Financial Crisis and Islamic Economics." , Available at: http://www.siddiqi.com/mns/CurrentFinancial CrisisAndlslamicEconomics.htm

Smolo, E and Mirakhor, A (2010) 'The global financial crisis and its implications for the Islamic financial industry', International Journal of Islamic and Middle Eastern Finance and Management, 3(4), pp. 372-385.

Sole, J (2007) Introducing Islamic Banks into Conventional Banking Systems, IMF Working Paper WP/07/175, Available at: http://www.imf.org/external/pubs/ft/wp/2007/wp07175.pdf

Sundararajan,V. and Errico, L. (2002) Islamic Financial Institutions and products in the global financial system: Key issues in risk management and challenges ahead. IMF working paper, IMF/02/192.

Turner (2009) 'The Turner Review A regulatory response to the global banking crisis'. Available at: http://www.fsa.gov.uk/pubs/ other/turner_review.pdf.

Verity, A. (2002) 'UKK to encourage Islamic mortgages',BBC. Monday, 18 February [Online]. Available at: http://news.bbc.co.uk/1/hi/ business/1826834.stm.

Yin, R. (1994) "Case study research: Design and methods", Second Edition. Beverly Hills, CA: Sage Publishing.

Zaher, T. and Hassan, M.K. (2001) 'A comparative literature survey of Islamic finance and banking'. Financial Market Institutions and Instruments, 10, pp. 155-199.

Zaidi, J.A. (2008) 'Shari'a Harmonization, Regulation and Supervision', Presented at: AAOIFI-World Bank, Islamic Banking and Finance Conference, Manama, Bahrain. Available at:http://www.ïrating.com/presentation/speech_Sh_Regulation_AAOIFI_2008.pdf 